Assessing impacts of habitat modification on a subtropical salt marsh: 20 years of monitoring.

Pat E.R Dale

Griffith School of Environment, Griffith University, Nathan, Australia, 4111

Corresponding author:

Professor Pat Dale

Griffith School of Environment,

Griffith University,

Nathan,

Queensland,

Australia 4111.

tel: +61 737357136

fax: +61 737356717

email: p.dale@griffith.edu.au 


\title{
Assessing impacts of habitat modification on a subtropical salt marsh: 20 years of monitoring.
}

Pat E.R Dale

Griffith School of Environment, Griffith University, Nathan, Australia, 4111

Keywords: Aedes vigilax, Habitat modification, Impacts, Mosquito control, Salt marsh, Runnel.

\begin{abstract}
The impacts of habitat modification for mosquito control by runnelling in a sub-tropical salt marsh in eastern Australia were evaluated over 20 years (1985-2005) on a quarterly basis. Runnels are shallow channels that connect isolated pools to the tidal inlet. Differences between the first month and the last were assessed as two snapshots in time and showed a similar nature of change between the two times for treatment and controls, though these were significant only for substrate moisture (higher in runnel samples) and salinity (lower in runnel samples). Over the whole 20 years the impacts at the Coomera site were to reduce mosquito larval populations, with small magnitude impacts on the environment. These were, for the runnel samples compared to controls: increased substrate moisture, lower substrate salinity, less dense and smaller Sporobolus and Sarcocornia, slightly lower and less saline water table and more crab holes. These differences reflected a similar direction of change for both runnel and control samples, in all the variables observed and may be associated with regional land use or climate or sea level changes. During the last five years substrate moisture was higher near runnels than controls and this may be a response to drought conditions over this period. The modification has had no maintenance.
\end{abstract}




\section{Introduction}

That salt marshes are important ecosystems is widely recognised and indicated by their protected status in Australia and internationally. That they may produce large numbers of disease vector mosquitoes is also well known. This leads to a need to manage the mosquito problem with minimal impact on the environment. In Australia the salt marsh mosquito, Aedes vigilax (Skuse), is a major vector of Ross River and Barmah Forest virus diseases. These are human polyarthritic diseases and, although not fatal, they are debilitating (MacKenzie et al.1998). Ross river virus has been the major arbovirus over recent decades with up to 8000 cases each year in Australia. The majority of cases are in Queensland (Russell 2002). For example, in 2003 Queensland had a total of 2517 out of a national total of 3841 cases (Miller et al. 2005). It exacts a social and economic cost to society that has been estimated to be between \$AUD1,000 and 2,500 per person (Boughton 1994; Harley et al. 2001; Ratnayake 2006).

Runnelling, a minor form of Open Marsh Water Management, was introduced in Queensland in 1985 to add another tool to the integrated management of the salt marsh mosquito problem. Runnelling has been described in Hulsman et al. (1989) and reviewed in the context of salt marsh management in Dale and Hulsman (1990) as an example of an approach that attempts to interfere with the environment as little as possible in order to manage the pest. Runnels are shallow spoonshaped channels that connect isolated salt marsh pools that produce mosquitoes to the tidal source. This increases connectivity between marsh and estuary, increasing predator access and flushing larvae from the marsh on an ebb tide. 
For areas that are suitable for runnelling it is a relatively low maintenance mosquito management method. That runnelling is an effective control for mosquitoes is evidenced by its implementation in Australia and the development of a dedicated 'runnelling machine' (Santagiuliana pers. comm.). As with all forms of mosquito control it is necessary to assess impacts on non-target aspects of the environment. Although Latchford (1997) assessed shortterm impacts (less than two years) in Western Australia, most assessment in Australia has been on the one reference site at Coomera Island in Queensland (Figure 1).

Previous research at the Coomera site has indicated that there were no significant effects of runnelling on marsh function after 15 months (Dale and Hulsman 1988); as identified from remote sensing after six years (Dale et al. 1996); on general marsh characteristics after eight years (Dale et al. 1993) and on marsh processes over a 14 year period (Dale and Dale 2002). Dale and Knight (2006) compared various habitat modification methods in south-east Queensland over a three year period and found that runnelling had a lesser impact than other methods, including Open Marsh Water Management. Some of the research on specific organisms at the Coomera site has shown effects of runnelling. For example, Breitfuss et al. (2003) showed that mangrove propagules were transported along runnels into the high marsh. However Jones et al. (2004) also showed that mangroves do not establish on the salt marsh in any way that differs from unmodified areas. Chapman et al. (1998) found some association between grapsid crab distribution and runnelling, but later research indicated that the relationship was not consistent across different marshes (Chapman et al. 2004). Breitfuss (2003) also noted that runnels affected the distribution and size structure of the gastropods, Salinator solida and Ophicardelus sp., but that the effect was site-specific and appeared to be related to increased soil moisture near runnels. On a positive note Breitfuss and Dale (2004) also showed that an endangered butterfly species was to be found in the area, some 19 years after modification. At a site to the north of Coomera 
Island, Connolly (2005) found a relationship between runnelling and nekton distribution, with reduced abundances of small fish close to runnels, at some times of the year.

The aim here is to summarise 20 years of post-runnelling monitoring at the Coomera Island reference site.

\section{Methods}

\section{Study area}

The location of the study area on Coomera Island (S27 $\left.51^{\prime}, \mathrm{E} 153^{\circ} 33^{\prime}\right)$, is shown in Figure 1. It is at the northern end of the Gold Coast, Queensland, and close to areas of rapid population growth. Vegetation is mainly Marine Couch (Sporobolus virginicus (L. Kunth)) and Samphire (Sarcocornia quinqueflora (Bunge ex Ung.-Stern)) with the Grey Mangrove (Avicennia marina (Forsk)) along the tidal inlet that floods the marsh. The problem mosquito species is Aedes vigilax (Skuse), a vector Ross River and Barmah Forest virus diseases. The larval habitats are mainly pools that are flooded on high tides and then isolated from the tidal source after the ebb tide. A small part of the 8 ha marsh (0.5 ha) was runnelled in November 1985. Runnels up to $0.30 \mathrm{~m}$ deep and $0.90 \mathrm{~m}$ wide linked isolated pools to the tidal source. The design followed patterns of water flow, as far as possible, identified using colour infrared aerial photographs and vegetation indicators such as areas of Sarcocornia and the short form of Sporobolus as well as field survey. There has been no maintenance since and there has been no larviciding of the runnelled area.

\section{INSERT FIG 1}




\section{Data collection}

The monitoring was originally based on the premise that vegetation would reflect general environmental conditions and that monitoring both vegetation and some environmental characteristics would indicate the impacts of runnelling. Details of the monitoring methods are in Hulsman et al. (1989). Briefly, the design is a treatment and control one. Treatment is runnelling, with samples located at right angles to runnels at distances of 0,1,2 and 4 metres from the runnel. The control samples were located at the same distances $(0,1,2,4 \mathrm{~m})$ from natural water bodies (pools and channels). To ensure similar tidal and rainfall conditions, controls are nearby (on average $40 \mathrm{~m}$ from treatments) and flooded by the same tidal inlet. There were 30 samples in all $(n=22$ treatment and $n=8$ control). The different number of treatment and control samples was because it was difficult to find suitable control sites. For the first 15 months monitoring was done every month within a few days of the lower of the Spring high tides. Preliminary data analysis of the environmental variables comparing the results of monthly and quarterly data indicated that quarterly monitoring would suffice, since there were no significant differences between the means. Monitoring was then carried out 4 times year and these data are used here. The data were collected from November 1985 to November 2005 inclusive, with the exception of one visit that was missed in February $1990(n=2430)$.

Mosquito larvae were sampled and counted at 25 fixed points in the runnelled area and then randomly, wherever water was found, in the surrounding 8 ha marsh (within approximately 200 $\mathrm{m}$ to the south, east and north of the runnelled area). Larval sampling was without replacement, with a $240 \mathrm{ml}$ dipper and 3 dips per sample.

Runnel depth was measured on each visit at four fixed locations: two in an upper runnel and two close to the connection to the tidal source of two runnels. 
The vegetation variables measured included measuring the size and density of Sporobolus and Sarcocornia in permanent $10 \times 10 \mathrm{~cm}$ quadrats. After nine years mangrove pneumatophores appeared in some quadrats and soon after crab holes were noted and these were added to the counting. Crab holes indicated crab activity and not crab population size.

The other environmental variables measured for the whole period included water table depth and salinity and substrate moisture content, salinity and $\mathrm{pH}$. Water table $\mathrm{pH}$ was measured from May 2001, as awareness of potential acid sulfate issues grew.

\section{Data analysis}

Students t-tests were used to test for significant differences between treatment and controls. Two sets of analyses were done. First were two snapshots in time. The treatment and control areas were compared at the start of the project in November 1985 and again at the end, in November 2005. Second, the data were analysed over the whole monitoring period $(n=2430)$. In addition some further analyses were carried out using ANOVA to explore some of the statistically, and potentially ecologically, significant results.

\section{Results}

The results are presented first for the beginning and the 20-year comparison (snapshots), and then for the whole time period for each variable (twenty years).

\section{Mosquito larvae}

\section{Snapshots}

At the start, within two months of runnel construction (January 2006), there was still an average of 70 larvae/dip (SD 63.6) in the runnelled area, and 147/dip (SD 187.2) in the 
surrounding marsh. By November 2005 there were no larvae in the runnelled area and a mean of 15/dip (SD 24.3) in the unrunnelled area.

Twenty years

Over the 20 years larval numbers varied. In the runnelled area there was a mean of 1.89 larvae/dip (SD 8.31) and a mean of 16.86 (SD 25.99) in the unrunnelled area. These were significantly different $(\mathrm{t}=5.757$, df $96, \mathrm{P}<0.0001)$. For $90 \%$ of observations in the runnelled area there were 2 or fewer larvae/dip compared to 54/dip for the unrunnelled area. Larvae were found in the runnelled site for the first 4 months after construction. After that, the mean for the runnelled site was 0.62/dip (1.93 SD) and for the unrunnelled site was 15.62 (23.05 SD).

\section{Runnel depth}

\section{Snapshots}

Runnel depths after 3 months and 20 years are shown in Figure 2. The two upper runnel sites (Sites 1 and 2) were very similar to the start at the end of the period. The lower sites (sites 3 and 4) were several centimetres shallower than at the start.

INSERT Figure 2

\section{Twenty years}

The runnel depths varied over the period as shown in Figure 3. Initially, and for a period of around 4 years, there was erosion at all sites. This continued in the upper runnel sites (Sites 1 and 2) until around year 10. After this some deposition has occurred with the result that after 20 
years the depths are, with the possible exception of Site 3, similar to those at the start (Figure 3). Note that had the research terminated after 3 years it would have been tempting to expect that erosion might have become a problem.

\section{INSERT Figure 3}

\section{Environment}

\section{Snapshots}

Some of the environmental variables differed significantly from their initial state after 20 years in both treatment and control (Table 1). In general, in 2005, the area was less acid, with lower density and size of both the dominant grass (Sporobolus) and the succulent (Sarcocornia), the water table was higher and it was more saline (in contrast to a lower salinity in the substrate, though this was not significant).

\section{INSERT TABLE 1}

There were significant or almost significant differences between treatment and control only for substrate moisture and its salinity at the start and again after 20 years: the runnel samples were generally wetter and less saline than the control ones, though the nature of the relationship had not changed from the start (Table 2).

\section{INSERT TABLE 2}


The effect of distance on the two plants was similar at the start and at the end and is summarised in Table 3 for the edge and furthest samples $(0 \mathrm{~m}, 4 \mathrm{~m})$.

\section{INSERT TABLE 3}

Sporobolus: At the start, at runnel samples, Sporobolus density and size increased with distance from runnel; at controls it decreased. At the end of the study the relationships were the same, though the density and size were lower, and, for the control samples, Sporobolus had disappeared.

Sarcocornia: At the start Sarcocornia density and size diminished with distance from the edge of a runnel; the reverse was so for the controls with Sarcocornia absent at the edges and relatively dense and large at the $4 \mathrm{~m}$ distance. By the end of the study treatment sites had become more similar to the controls with no Sarcocornia at the edge and a small amount at the 4 $\mathrm{m}$ distance.

\section{Twenty years}

The remaining section presents the results over the whole time period. The results are summarised in Table 4, including some information on the statistically non-significant ones that may be important ecologically.

\section{INSERT TABLE 4}


Over the whole period all but three of the variables differed significantly between treatment and control. These were substrate $\mathrm{pH}$, water table $\mathrm{pH}$ and pneumatophore density. Significant effects of runnelling were found for the other variables as shown in Table 4. However, although statistically significant, the differences were often quite small.

Vegetation: The vegetation measures were variable as indicated by the SDs. The density and size of Sporobolus was greater in the runnel than in the control samples and the reverse was so for Sarcocornia. However, for Sporobolus, both density and size had declined for both treatment and control over the time period (Table 1). Exploring the plant data in more detail there were no seasonal effects for Sporobolus but there were significant effects of season on Sarcocornia with maximum density and size in Summer (February) ( $\mathrm{t}=4.4277 \mathrm{df} 3,2426, \mathrm{P}<0.01)$. The relationship was similar for both runnel and control samples.

The ANOVA results for distance from the runnel or control were significant only for vegetation (Table 5). At the $4 \mathrm{~m}$ distance from runnels Sporobolus density and size was greater than close to the runnels $(\mathrm{P}<0.0001)$, despite the overall decline over the 20 years. In contrast, for the controls Sporobolus density and size was less at $4 \mathrm{~m}(\mathrm{P}<0.0001)$ and this was mirrored by an increase in the relative size and density of Sarcocornia $((\mathrm{P}<0.0001)$, again despite an overall decline.

\section{INSERT TABLE 5}

Substrate: Substrate $\mathrm{pH}$ increased between the beginning and end of the study but did not differ significantly between treatment and control. Substrate moisture was very slightly higher and less saline overall in the runnel samples than in the controls and the levels had not changed greatly over the time period. Figure 4 shows when the substrate moisture started to differ 
between the control and runnel samples. Although the changes were similar for both controls and runnels, there was some divergence during the last 6 years (2000-2005 inclusive) with increased wetness in the runnel samples.

\section{INSERT FIGURE 4}

Water table: the water table was slightly lower overall at the runnel samples and slightly less saline that at the controls but $\mathrm{pH}$ did not differ. The differences were less overall than those at the two snapshots in time as shown in Table 1, although the nature of the differences was similar.

Other: The first pneumatophores were noticed and recorded in November 1994 at $2 \mathrm{~m}$ from a control sample and in the following May at the edge of a runnel. Overall there were no significant differences between treatment and control. Exploring the pneumatophore data in more detail showed significant positive relationships between their density and substrate $\mathrm{pH}$ and water table salinity and a negative relationship with substrate moisture and Sporobolus density and size. Crab holes appeared first at a sample $1 \mathrm{~m}$ from a runnel in November 1995 and by May 1996 the first crab hole appeared at a control sample ( $2 \mathrm{~m}$ location). Exploring the crab hole relationships in more detail, for only those samples that contained them, there were significant relationships with both substrate and water table $\mathrm{pH}(\mathrm{t}=4.51$, df $466, \mathrm{P}<0.0001 ; \mathrm{t}=3.06$, df $205, \mathrm{P}<0.01$ respectively) and with Sarcocornia density and size $(\mathrm{t}=-2.03$, df 466, $\mathrm{p}<0.05 ; \mathrm{t}=-3.07$, df $465, \mathrm{P}<0.01$ respectively). There were greater numbers of crab holes as $\mathrm{pH}$ increased and fewer with increased density and size of Sarcocornia.

\section{Discussion}

An important outcome is that the long-term study has shown how the system has changed over 20 years and this is not what might have been expected had the project terminated at the 3 
year point (that is often the funding timeframe). That the differences between treatment and control were statistically significant over the whole 20 -year period tends to obscure the fact that the trends for each variable were generally similar. This is evidenced in the start and end data in Tables 1 and 2 and also in Figure 4. The significant differences were related to the large number of degrees of freedom in the data and it was not possible to identify exactly when significant changes occurred. When the annual pattern was examined for each variable there was a similar trend in the pattern of change in all the variables (as exemplified by Figure 4 for substrate moisture, discussed below).

As well as assessing impacts, additional insights have been developed from the research into marsh processes (Dale and Dale 2002). It could be argued that analysis at the process level is a good indicator of general impact. However the ecological significance, if any, may not be obvious until much more time has elapsed. There has also been a multiplier effect with other related studies adding value to the long-term study.

Assessing the impacts of runnelling over 20 years has provided information on changes at the very local level in the salt marsh. The delay in large larval reduction was noted earlier (Hulsman et al. 1989) and was attributed to the time taken for predators to access the marsh regularly. It was also conjectured that oviposition may have been affected (because of changes in soil moisture), but although this appears to be so in some runnelled sites, it is not apparent at Coomera (Dale et al. 2002). There were also fewer mosquito larvae in the surrounding marsh than at the start and this may reflect a broader impact of runnelling on mosquitoes, perhaps by reducing the adult population locally, or it may reflect mosquito control (larviciding) reducing populations generally in the area.

Runnel depth and erosion/sedimentation appear to be related to position along the runnel, with upper areas eroding for longer than lower locations. It is probable that the material removed 
from the upper parts contributed to sedimentation at lower runnel sites. One factor increasing the retention of sediment may be the expansion of pneumatophores of the mangrove Avicennia marina, though concerns that runnelling would lead to widespread invasion of the marsh appear to be unfounded (Jones et al. 2004).

That the runnel sites were wetter and less saline than the controls even at the start reflects the planning rationale that runnels were to be located as far as possible along the natural pathways of water movement: these thus would be expected to be wetter, more flushed and hence less saline than the controls that were generally located adjacent to pools, to match up at least with water bodies, as water is associated with runnels.

Changes between the start of the project and 20 years later do not appear to be related to runnels directly. The overall reduction in Sporobolus density and size is consistent with the observed expansion of mangroves (Avicennia marina) into salt marsh, not only at Coomera Island, but in other parts of the region (e.g. McTainsh et al. 1986; Saintilan and Williams 2000; Jones et al. 2004) and attributed to land-use, sea level or climate changes, but not to runnelling. At Coomera Island increased wetness may have contributed to the decline in Sporobolus, as the plant tends to occupy a high marsh and hence somewhat dry position (Adam et al. 1988). Even at the start of the project the Sporobolus density and size was greater at $4 \mathrm{~m}$. distance than close to the runnels. This is not surprising, as the short form Sporobolus was selected for runnel construction as it indicates higher salinity and potentially natural directions of water flow. That the runnel samples became more similar to the controls in their Sarcocornia characteristics is also not surprising as the runnels were designed to mimic natural channels and so could be expected to behave as such. Although soil moisture itself was not related to the distance from runnel at the times it was measured (Spring high tides), drier conditions further from runnels might be expected in the periods of low tides. Increasing wetness generally is also consistent with 
the appearance of mangrove pneumatophores at the site after nine years.

The increasing difference shown in Figure 4 between the substrate moisture in runnel and control samples in the last 5 years of the research, may be related to drought. From 2001 onwards rainfall was below average in Queensland and locally rainfall was either below average (in the lowest $30 \%$ of historical data ) or very much below (in lowest 10\%) (data from Bureau of Meteorology, Australia). This would be likely to lead to controls drying more than runnels, as they are not flushed as often by tides and hence may rely more on rainfall for substrate moisture replenishment. This is consistent with the higher salinity of the controls and suggests that under extreme conditions there may be effects of the modification. There were similar situations, though les pronounced when rainfall was relatively low between 1985 and 1989 and again between 1992 and 1994. Increased level and salinity of the water table at a snapshot in time, albeit it at a similar stage of the tidal cycle, may be a chance event or could be related to, for example, changes in sea level with increased saline water incursion into the groundwater: the site is underlain by a permeable sandy substrate. However examining the data over time did not reveal a clear trend.

Issues that were not contemplated at the start became important during the research and were included in an adaptive research framework. First there was, at the start of the project, relatively little awareness of and concern about acid sulfate soils. The study site is underlain by potential acid sulfate soils. Fortunately the runnels did not penetrate the layer and, even if they had, the increased wetness and buffering effect of seawater would probably have avoided a problem generally (Saffigna and Dale 1999; Alsemgeest et al. 2005). It is reassuring that $\mathrm{pH}$ increased, never fell below the action level of 4 , and did not show a significant effect of runnelling.

Second, the appearance of mangrove pneumatophores led to their inclusion in the data collection. Although pneumatophore density was not directly associated with runnelling, it was 
related to some of the variables that may be affected by runnelling. Thus increases in substrate $\mathrm{pH}$ or water table salinity associated with runnelling may lead to increased pneumatophore density, as might also decreases in Sporobolus density and size. At the Coomera site pneumatophores do not appear to have impeded the mosquito control function, but may act as a sediment trap that could eventually restrict water movement.

Third, the appearance of crab holes led to their inclusion in the data collection. Their number was significantly related to acidity over the time period associated with higher, less acid $\mathrm{pH}$. This may reflect crab avoidance of relatively acid areas; seawater has a buffering effect on acidity and so lower $\mathrm{pH}$ and fewer crab holes may also relate to tidal flooding patterns. The association between Sarcocornia size and density and smaller numbers of crab holes may be a result of vegetation density impeding burrowing. Other research at the Coomera site has shown associations between runnelling and grapsid crabs based on trapping experiments (Chapman et al. 2004) with increased numbers of Helograpsus haswellianus in the unrunnelled area, but increased numbers of Parasesarma erythrodactyla in the runnelled area.

Finally caution is urged in applying the results to other salt marshes without careful site evaluation, as marshes can vary significantly and results of runnelling research are not always consistent across sites (see for example, Chapman et al. 2004; Breitfuss 2003; Dale et al. 2002).

\section{Conclusion}

One value of this research is that it has shown the longer-term impacts of runnelling to be small yet statistically significant, compared to other specific and shorter-term evaluations that found little or no significant effects. The effects at the 20-year point were not necessarily those that would have been expected had the research terminated after 3 years. Whether the impacts are ecologically significant may take a lot longer to assess. Overall the effects of runnelling at the 
Coomera site were to reduce mosquito larval populations with small magnitude impacts on the environment, with trends similar to those for the control samples. The effects in the runnelled area were: increased substrate moisture, lower substrate salinity, less dense and smaller Sporobolus and Sarcocornia, slightly lower (c $0.01 \mathrm{~m}$ than control) and less saline (c 1ppt lower than control) water table and more crab holes indicating crab activity. It has also provided a modification with low (in this case no) maintenance. The similar trends in both treatment and controls may indicate regional changes in land use and their impacts on coastal systems or relate to climate or sea level change, as intertidal ecosystems are likely to be sensitive to quite small changes in these.

\section{Acknowledgements}

The long-term assistance of the Gold Coast City Council both in-kind (with field assistance and travel) and financial is very gratefully acknowledged. Other sources of support over the period include the Queensland State Health Department, Local Authorities Research Committee and Griffith University. Thanks too to the many student assistants in the field and laboratory and particularly to Dave Bluhdorn and Jon Knight for their long-term commitment. I would like to thank the reviewer whose ideas stimulated further exploration of the data.

\section{References}

Alsemgeest G., Dale P. and Alsemgeest, D. 2005. Evaluating the risk of potential acid sulfate soils and habitat modification for mosquito control (runnelling): comparing methods and managing the risk. Environ. Manage. 36 (1): 152-161, http://dx.doi.org/10.1007/s00267-003$\underline{0112-4}$

Adam P, Wilson N.C. and Huntley B. 1988. The phytosociology of coastal saltmarsh vegetation in New South Wales. Wetlands (Australia) 7(2): 35-84. 
Boughton C.R. 1994. Arboviruses and disease in Australia. Med. J. Aust. 160: 27-28.

Breitfuss M.J. 2003. The Effects of Physical Habitat Modification for Mosquito Control, Runnelling, on Selected Non-Target Saltmarsh Resources. PhD Thesis, Griffith University, Nathan, Queensland, Australia 4111.

Breitfuss M.J., Connolly R.M. and Dale P.E.R. 2003. Mangrove distribution and mosquito control: transport of Avicennia marina (Forsk.) propagules by mosquito-control runnels in southeast Queensland saltmarshes. Estuar. Coast. Shelf Sci. 56(3-4): 573-579.

Breitfuss MJ and Dale PER. 2004. The endangered Illidge's Ant Blue Butterfly, Acrodipsas illidgei, from an intertidal habitat managed for mosquito control. J Amer. Mosq. Cont. Assoc. 20 (4):91-93.

Bureau of Meteorology (Australia) 2007. www.bom.gov.au/ and http://www.bom.gov.au/cgibin/silo/reg/cli_chg/timeseries.cgi (accessed April 6 2007)

Chapman H, Dale P.E.R. and Kay B.H. 1998. A method for assessing the effects of runnelling on salt-marsh grapsid crab populations. J. Amer. Mosq. Contr. Ass. 14: 61-68.

Chapman H.F., Breitfuss M.J., Dale P.E.R. and Thomas P. 2004. Influence of saltmarsh habitat modification for mosquito control on shore crab populations in southeast Queensland. Wetlands (Australia) 22(1): 1-10.

Connolly R.M. 2005. Modification of saltmarsh for mosquito control in Australia alters habitat use by nekton. Wetl. Ecol. Manag. 13: 149-161.

Dale P.E.R. and Hulsman K. 1988. To identify impacts in variable systems using anomalous changes: a salt marsh example. Vegetatio 75: 27-35.

Dale P.E.R and Hulsman K. 1990. A critical review of salt marsh management methods for mosquito control. Crit. Rev. Aquat. Sci, 3: 281-311. 
Dale P.E.R., Dale P.T., Hulsman K. and Kay B.H. 1993. Runnelling to control saltmarsh mosquitoes: long-term efficacy and environmental impacts. J. Amer. Mosq. Contr. Ass. 9 (2): 174-181.

Dale P.E.R., Chandica, A.L. and Evans M. 1996. Using image subtraction and classification to evaluate change in subtropical intertidal wetlands. Int. J. of Remote Sens. 17: 703-719.

Dale P.E.R. and Dale M.B. 2002. Optimal classification to describe environmental change: pictures from the exposition. Commun. Ecol. 3 (1): 19-29.

Dale P.E.R., Chapman H., Brown M.D., Ritchie S.A., Knight J. and Kay B.H. 2002. Does habitat modification affect oviposition by the salt marsh mosquito Ochlerotatus vigilax (Skuse) (Diptera:Culicidae)?Aust. J. Entomol. 41:49-54.

Dale P.E.R and Knight J.M. 2006. Managing salt marshes for mosquito control: impacts of runnelling, Open Marsh Water Management and grid-ditching in sub-tropical Australia, Wetl. Ecol. Manag. 14 (3): 211-220. http://dx.doi.org/10.1007/s11273-005-1113-2

Harley D.O., Sleigh A. and Ritchie S.A. 2001. Ross River virus transmission, infection, and disease: a cross-disciplinary review. Clinical Microbiology Review 14(4): 909-932.

Hulsman K, Dale P.E.R and Kay B.H. 1989. The runnelling method of habitat modification: an environment focussed tool for salt marsh management. J. Amer. Mosq. Contr. Ass. 5: 226234.

Jones J., Dale P.E.R., Chandica A.L. and Breitfuss M.J. 2004. Distribution changes of the Grey Mangrove Avicennia marina (Forsk.) using large scale aerial color infrared photographs: are the changes related to habitat modification for mosquito control? Estuar. Coast. Shelf Sci. 61(1):45-54.

Latchford J. 1997. The effectiveness and environmental impacts of runnelling, a mosquito control technique.PhD thesis, Murdoch University, Western Australia. 
MacKenzie J.S., Broom A., Hall R.A., Johansen C.A., Lindsay M.D., Phillips D.A., Ritchie S.A., Russell R.C. and Smith D.W. 1998. Arboviruses in the Australian region, 1990 to 1998. Commun. Dis. Intelligence (Australia) 22(6): 93-100.

McTainsh G., Iles B. and Saffigna P. 1986. Spatial and Temporal Patterns of Mangroves at Oyster Point Bay, South East Queensland, 1944-1983. Proc. R. Soc. Qd. 99: 83-91.

Miller M, Roche P, Yohannes K, Spencer J, Bartlett M, Brotherton J, Hutchinson J, Kirk M, McDonald A, Vadjic C. 2005. Australia's Notifiable diseases status, 2003 Annual report of the National Notifiable Diseases Surveillance System. Commun. Dis. Intelligence (Australia) 25 (1): 45-47.

Ratnayake J. (2006) The valuation of social and economic costs of mosquito -transmitted Ross River virus. PhD thesis, Griffith University Nathan Queensland 4111.

Russell R.C. 2002. Ross River Virus: Ecology and Distribution. Ann. Rev. Entomol. 47:1-31.

Saffigna P.G. and Dale P.E.R. 1999. Acid sulfate soils in intertidal mosquito breeding habitats and implications for habitat modification. J. Amer. Mosq. Contr. Ass. 15 (4): 520-525.

Saintilan N. and Williams R. 2000. The Decline of Saltmarshes in Southeast Australia: Results of Recent Survey. Wetlands (Australia) 18: 49-54. 


\section{List of Figures}

Figure 1. Location of study area.

Figure 2. Runnel depth at 3months and at 20 years after runnel construction. Sites 1 and 2 are in upper runnel; Sites 3 and 4 are at the tidal source connection of two runnels.

Figure 3. Runnel depths every 3 months, November 1985 to November 2005.

Figure 4. Annual pattern of substrate moisture (g/g) 1985-2005. 